\title{
Determination of optimum insulation thicknesses for salinity gradient solar pond's bottom wall under different climate conditions
}

\author{
Hossein Beiki ${ }^{1} \cdot$ Ehsan Soukhtanlou ${ }^{2}$
}

Received: 9 December 2019 / Accepted: 15 June 2020 / Published online: 25 June 2020

(c) Springer Nature Switzerland AG 2020

\begin{abstract}
The salinity gradient solar pond is one of the most efficient tools that can be used to collect, convert and store the solar energy. The performance of solar pond specially depends on heat losses from it. The performance of the solar pond could be improved by using the thermal insulation on the bottom and sides of the solar pond. Determination of insulation thickness is very important; it is commonly estimated based on the climate conditions, insulation materials and economic parameters. Therefore, in this study, the optimum insulation thickness, cost and energy savings were calculated for a salinity gradient solar pond under different climate conditions. An economic analysis was applied to obtain the optimum value of the insulation thickness when the polyurethane was used as the insulation material. For this purpose, the temperature of the lower layer of the solar pond was calculated using the one-dimensional unsteady heat transfer model inside the pond. The model and the literature experimental lower layer temperatures showed a good agreement, with the average deviation of $5 \%$. They also had the same trend in all months of the year. The results revealed that the optimum insulation thickness strongly depended on the solar irradiance and the ambient temperature. This study also found that by introducing the optimum insulation thickness of $62-122 \mathrm{~mm}$, according to the climate conditions, in the solar pond's bottom wall, the energy saving could be enhanced by $36.7-55.2 \%$ as compared with the solar pond without insulation.
\end{abstract}

Keywords Optimum insulation thickness · Salinity gradient solar ponds · Cost-benefit analysis · Different climate conditions

\begin{tabular}{|c|c|c|c|}
\hline \multicolumn{2}{|c|}{ List of symbols } & $i$ & Interest rate \\
\hline \multicolumn{2}{|c|}{$A \quad$ Surface area $\left(\mathrm{m}^{2}\right)$} & $I R$ & Iranian Rials \\
\hline$c$ & Salt concentration $\left(\mathrm{kg} / \mathrm{m}^{2}\right)$ & $I_{R}$ & Solar irradiance $\left(\mathrm{W} / \mathrm{m}^{2}\right)$ \\
\hline$c_{p}$ & Specific heat capacity of the fluid $\left(\mathrm{J} / \mathrm{kg}^{\circ} \mathrm{C}\right)$ & k & Thermal conductivity $\left(\mathrm{W} / \mathrm{m}^{\circ} \mathrm{C}\right)$ \\
\hline$C_{A}$ & Cost of thermal insulation per unit volume & LCZ & Lower convective zone \\
\hline & $\left(\mathrm{IR} / \mathrm{m}^{3}\right)$ & $M_{s}$ & Ratio of the annual maintenance and opera- \\
\hline$C_{E}$ & Cost of energy (IR/kWh) & & tion cost to the original first cost \\
\hline$C_{i}$ & Cost of thermal insulation $\left(\mathrm{IR} / \mathrm{m}^{2}\right)$ & $N$ & Life-cycle period (year) \\
\hline$d$ & Inflation rate & NCZ & Non-convective or gradient zone \\
\hline$D$ & Layer thickness (m) & $P_{1}$ & Ratio of life-cycle energy cost to the first year \\
\hline$E$ & Absorption radiation energy $\left(\mathrm{W} / \mathrm{m}^{3}\right)$ & & energy cost \\
\hline$E_{a}$ & Annual energy requirement (kWh) & $P_{2}$ & Ratio of capital investment to the initial \\
\hline$\Delta g$ & Distance in $z$ direction $(\mathrm{m})$ & & investment \\
\hline$h_{i}$ & Heat transfer coefficient $\left(\mathrm{W} / \mathrm{m}^{2} \mathrm{~K}\right)$ & $Q$ & Heat transfer rate $(\mathrm{W})$ \\
\hline
\end{tabular}

\footnotetext{
$\triangle$ Hossein Beiki, hbeiki@qiet.ac.ir; Ehsan Soukhtanlou, e_sukhtanlu@yahoo.com | Department of Chemical Engineering, Quchan University of Technology, Quchan 67335-94771, Iran. ${ }^{2}$ Department of Mechanical Engineering, Engineering Faculty, Ferdowsi University of Mashhad, Mashhad, Iran.
} 


\begin{tabular}{|c|c|}
\hline$R_{\text {tot }}$ & Thermal resistance (m K/W) \\
\hline$R_{\mathrm{v}}$ & Ratio of the resale value of the first cost \\
\hline$s$ & Energy cost saving for heating $\left(\mathrm{IR} / \mathrm{m}^{2}\right)$ \\
\hline$t$ & Time \\
\hline$\Delta t$ & The total operating time of solar pond $(\mathrm{h})$ \\
\hline$T$ & Temperature $(\mathrm{K})$ \\
\hline$U$ & Overall heat transfer coefficient (W/m K) \\
\hline UCZ & Upper convective zone \\
\hline$x$ & Insulation and wall thickness (m) \\
\hline$y$ & Space coordinate in Cartesian system \\
\hline$\Delta y$ & Distance in y direction $(\mathrm{m})$ \\
\hline$z$ & Space coordinate in Cartesian system \\
\hline$\Delta z$ & Distance in z direction $(\mathrm{m})$ \\
\hline$\zeta$ & $\begin{array}{l}\text { Fraction of direct radiation, which is } \\
\text { changed to diffusive radiation at the shaded } \\
\text { area }(30 \%)\end{array}$ \\
\hline$\eta_{s} \backslash$ eta_ $\{s\}$ & Performance coefficient \\
\hline$\rho$ & Density $\left(\mathrm{kg} / \mathrm{m}^{3}\right.$ \\
\hline
\end{tabular}

\section{Subscripts}

$\begin{array}{ll}\text { amb } & \text { Ambient } \\ \mathrm{C} & \text { Cement } \\ \mathrm{e} & \text { Sunny surface area } \\ \mathrm{g} & \text { Ground } \\ \mathrm{i} & \text { Iteration number } \\ \text { ins } & \text { Insulation } \\ \mathrm{L} & \mathrm{LCZ} \\ \mathrm{g} & \text { Energy loss from the LCZ to the ground } \\ \mathrm{LN} & \text { Energy loss from the LCZ to the NCZ } \\ \mathrm{s} & \text { Energy loss from the LCZ to sides } \\ \text { Lsr } & \text { Total radiation energy entering into the LCZ } \\ \mathrm{N} & \text { NCZ } \\ \mathrm{Nsr} & \text { Total radiation energy entering into the NCZ } \\ \text { sh } & \text { Shaded surface area } \\ \mathrm{U} & \mathrm{UCZ} \\ \text { unins } & \text { Without insulation }\end{array}$

\section{Superscript}

$n \quad$ Iteration number

\section{Introduction}

Each second of the modern industrial life depends on energy. Because of the rapid growth of world population and industrial development, energy demand is increasing. Accordingly, fossil fuels, which are valuable energy sources, are decreasing. So it is necessary to use energy efficiently and to replace fossil fuels by renewable energy resources such as biomass $[9,19,25]$ solar energy $[10,22$, $28,34,43]$ and alternative clean fuels such as dimethyl ether [8]. Without any doubt, solar energy is the most important and extensive renewable energy resource, in spite of the fact that the power of the sun's light and heat has a random and unstable nature. Therefore, it could be said that solar energy is a cyclic energy resource. Because of this limitation, solar energy storage has been considered $[1,3,13,14,17,27,32]$ to provide the energy of systems over the night and in the cloudy weather. As one of the most widely used solar energy storage equipment, in the large scale, we can mention solar ponds, which are pools of salt water that can be used to collect and store solar energy. Almost over 115 years ago, the solar pond was introduced by Kalecsinsky [30]. A lot of experimental studies have been reported on the manufacture, operation and stability of solar ponds in different radiation zones and countries $[1,2,13,17,32,35,38]$.

Liu et al. [32] investigated the thermal performance of the salt gradient solar pond both experimentally and numerically. They observed that the temperature of the trapezoidal pool was generally higher than that in the rectangular one and heat losses from the lower layer were reduced in the trapezoidal structure. The effect of nanofluids, which are homogenous suspensions of nano-sized material usually used to promote heat [42], on the thermal performance of a two-layer solar pond was numerically investigated, revealing that nanofluids, which were used in the lower layer, could improve the thermal performance and the storage capacity of the solar pond (Al-Nimr and Al-Dafaie 2014). By using spiral coils with different shapes of cross sections, Khodabandeh et al. [29] numerically investigated the nanofluid application to enhance heat extraction from the solar pond. Their numerical results showed that the heat transfer coefficient at lower flow rates was not dependent on the shape of flow cross section. The highest and lowest heat transfer coefficients belonged to the elliptical and rectangular cross sections, respectively. Similarly, using solar pond extracted heat for ejector refrigeration cycle coupled with a thermoelectric generator, cooling production was carried out, showing that under optimum conditions, the energy and exergy efficiencies were about $28.26 \%$ and $29.95 \%$, respectively [36]. Atiz et al. [7] investigated the energy and exergy of a cylindrical solar pond that integrated and nonintegrated with solar collectors. They showed that the highest and lowest energy and exergy efficiencies belonged to the solar pond with four collectors and without collector, respectively. Sayer et al. [40] examined the zonal thickness variation effect on the lower convective zone (LCZ) and upper convective zone (UCZ) temperature. They revealed that the optimum thicknesses of the non-convective zone (NCZ) and UCZ were about 2 and $0.2 \mathrm{~m}$.

Using a one-dimensional unsteady mathematical model, the thermal behavior of a solar pond and the ground beneath it was investigated by Amigo and Suarez [6]. The authors found that adding insulation at the bottom of the solar pond was only beneficial when the water 
table was shallow. Abdullah et al. [1] constructed a solar pond with a surface area of $113 \mathrm{~m}^{2}$ for sustained extraction of thermal energy. They showed that their solar pond thermal efficiency was about $13 \%$ and it seems reasonable for the solar pond. Wang and Yagoobi [44] applied a onedimensional model for studying the effect of water turbidity on the thermal performance of a solar pond. Their results demonstrated that turbidity played an important role in the thermal performance of solar ponds. They also obtained that turbidity must be kept as low as possible to enhance solar pond efficiency.

Solar ponds performance depends on several parameters. The performance of the solar pond can be enhanced with decreasing heat losses from the solar pond. Many researchers have investigated solar ponds in the last decays; however, the improvement and optimization of the construction of the solar ponds can be regarded as a challenge [16]. Wang and Akbarzadeh [45] obtained the optimum thickness of the gradient layer under various conditions. They investigated the effect of ground losses on the performance of solar pond and concluded that, in the case of wet soil with the high level of the underground water, the thermal insulation should be used for the solar pond walls. Beniwal et al. [11] studied the effects of the surrounding insulation at the bottom of the solar pond on the optimum thickness of the non-convection layer. They used five different insulation materials, including dry sand, mud powder, dry cement, marble dust and mica powder. They indicated that heat losses were reduced to a minimum amount by using $0.2 \mathrm{~m}$ thickness dust wall. Jubran et al. [23] studied the potential of using locally available materials and local clays as lining materials for solar ponds. The local clays have obtained from five regions in Jordan, namely Amman, the Dead Sea, Irbid, Karak and Tafilah. They also obtained the optimum moisture for clays used as insulation material. Their results demonstrated that Amman clays were a good choice as lining materials for solar ponds because of the lowest permeability values. They also introduced an efficient, cheap lining scheme consisted of compact local clay with low-density polyethylene film sandwiched between the clays. By using a two-dimensional ground heat losses model, Sezai and Tesdemiroglu [41] simulated the effect of bottom reflectivity on ground heat losses for solar ponds. They found that the ground heat losses were almost insensitive to bottom reflectively.

Based on the mentioned studies, the heat losses from the bottom of the solar pond can influence its performance, and it seems that thermal insulation is the most important way to reduce the heat losses from the bottom of the solar pond. Also, the heat losses from solar pond walls depend on the thermal insulation thickness. The heat losses can be decreased with increasing the insulation thickness, but costs of insulation increased, too. Therefore, it is desired to find the optimum insulation thickness to reduce the total cost of energy consumption and insulation materials. On the other word, finding the optimum insulation thickness is very necessary to minimize the total cost of insulation and energy saving. In this study, the temperature of the lower layer of the solar pond was obtained by solving the one-dimensional governing equation. Based on the temperature of the lower layer, the optimum insulation thickness of the bottom of the solar pond, as well as cost saving and energy saving, was calculated for various solar radiation zones of Iran by using the cost-benefit analysis. In this work, polyurethane was used as an insulation material.

\section{Data collection}

\subsection{Climate}

The performance of solar ponds depends on climate conditions [37]. To investigate the effect of the climate conditions on the performance of the solar pond, four different zones were selected based on the average annual sum of solar irradiance. Figure 1 shows the different selected solar radiations zones of Iran in terms of climate conditions. The average annual sum of solar irradiance was almost between 1200 and $2300 \mathrm{kWh} / \mathrm{m}^{2}$ in these zones. To exactly study, four cities of Bandar Abbas, Tehran, Ardabil and Rasht were selected as zones 1 to 4, respectively. The geographic data for these selected cities are presented in Table 1.

Since the sun's azimuth angle, altitude and the daily sunshine period are different for each region, the amount of the solar irradiance could be different in the selected zones. The performance of the solar pond could depend on the hourly solar irradiance. Based on the Duffie and Backman's method [15], the hourly solar irradiance was calculated for four cities. Figure 2 presents the average daily solar irradiance in these cities. According to Fig. 2, solar irradiance increases from zone 1 to zone 4 .

In addition, the performance of solar ponds depends on the ambient temperature. Table 2 shows the average monthly ambient temperature in the selected cities based on 8 years of historical weather readings. According to the average monthly ambient temperature for different cities, Bandar Abbas and Ardabil were found to be the warmest and coldest cities in the selected zones, respectively.

\subsection{Heating generation}

Iran has the one of the largest natural gas reserves in the world (almost $15.8 \%$ of the world's total). There are almost 
Fig. 1 Four solar radiation zones [18] and the location of the selected cities
Table 1 Geographic data for selected cities

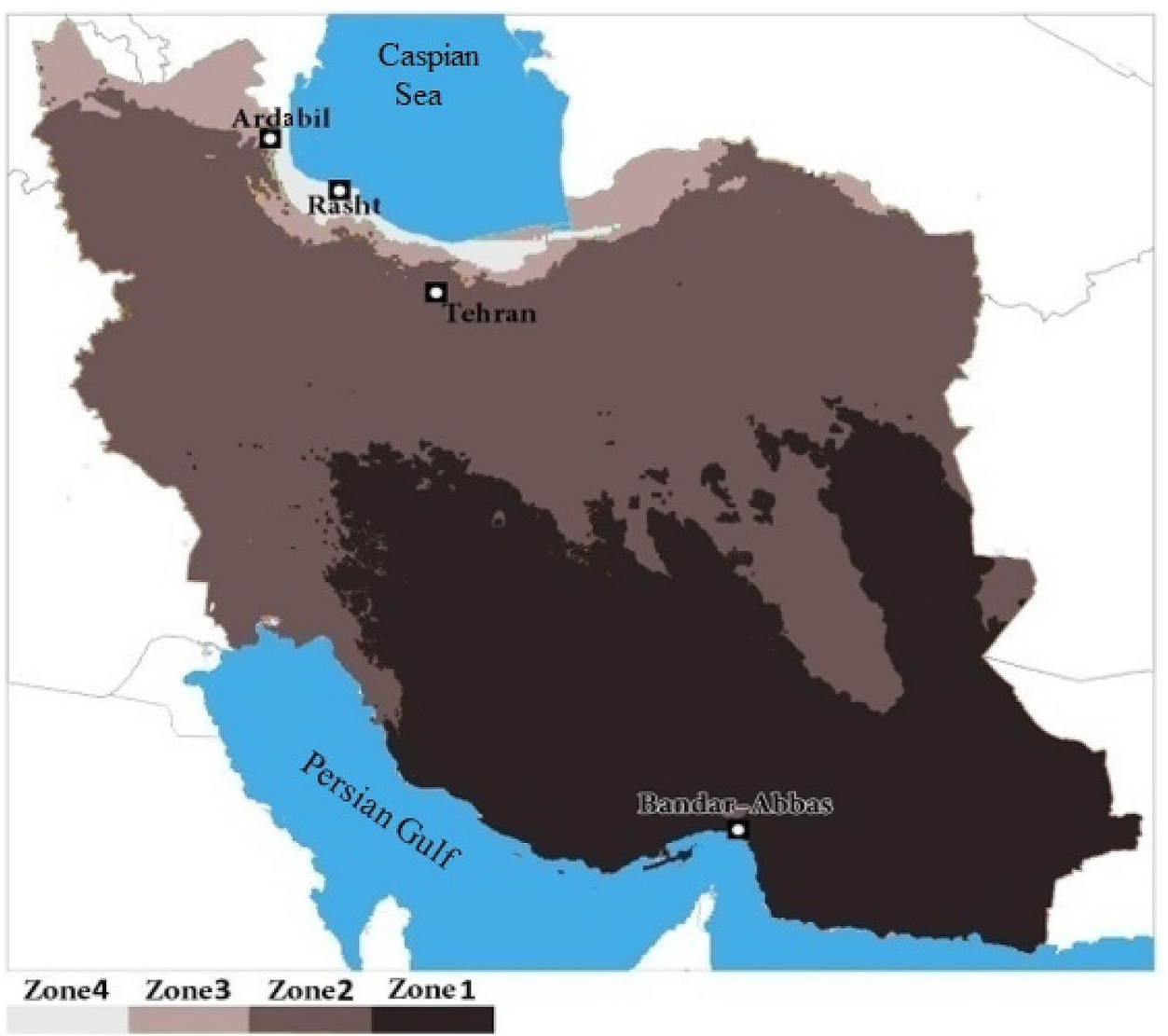

\begin{tabular}{lllll}
\hline City & Latitude & Longitude & Elevation $(\mathrm{m})$ & Solar irradiance $(\mathrm{kWh} / \mathrm{m} 2)$ \\
\hline Bandar Abbas & 27.1 & 56.2 & 10 & $2000 \leq$ zone 1 \\
Tehran & 35.4 & 51.2 & 1191 & $1700 \leq$ zone $2 \leq 2000$ \\
Ardabil & 38.5 & 46.1 & 1332 & $1400 \leq$ zone $3 \leq 1700$ \\
Rasht & 37.1 & 49.3 & 5 & Zone $4 \leq 1400$ \\
\hline
\end{tabular}

1046 trillion cubic feet natural gas reserves in Iran [20]. Heating buildings, desalination, drying, etc. are achieved by natural gas in almost all of the cities. Therefore, in this study, natural gas was considered for comparison. The cost of natural gas for industrial usage has been considered to be $1000 \mathrm{IR} / \mathrm{scm}(42,000 \mathrm{IR}$ (Iranian Rial)=1 US\$).

\section{Salinity gradient solar pond}

Generally, salinity gradient solar pond (SGSP) consists of three layers; it can be seen in Fig. 3 .

1. The UCZ: This layer contains a minimum salinity level (almost 3\%) and almost constant temperature closed to the ambient temperature. If the thickness of this layer is increased, the amount of absorption of solar irradiation will be enhanced; on the other hand, the effect of the surface winds will decrease. Therefore, the depth of this layer is usually between 10 and $50 \mathrm{~cm}$.

2. The LCZ: In this layer, the thermal energy is collected and stored. The amounts of salinity and temperature are maximum in the LCZ [31]. In this layer, the heat transfer happens to the non-convection layer and the ground. Depending on the temperature and the amount of stored heat, the depth of this layer is selected about 1 to $3 \mathrm{~m}$.

3. The NCZ: In this layer, the temperature and salinity increase from upper to lower layers. Because this layer has enough salinity gradient, heat transfer from the lower layer to the upper layer occurs by conduction instead of convection. The thickness of this layer varies between 1 and $1.5 \mathrm{~m}$. 
Fig. 2 The solar irradiation for different cities
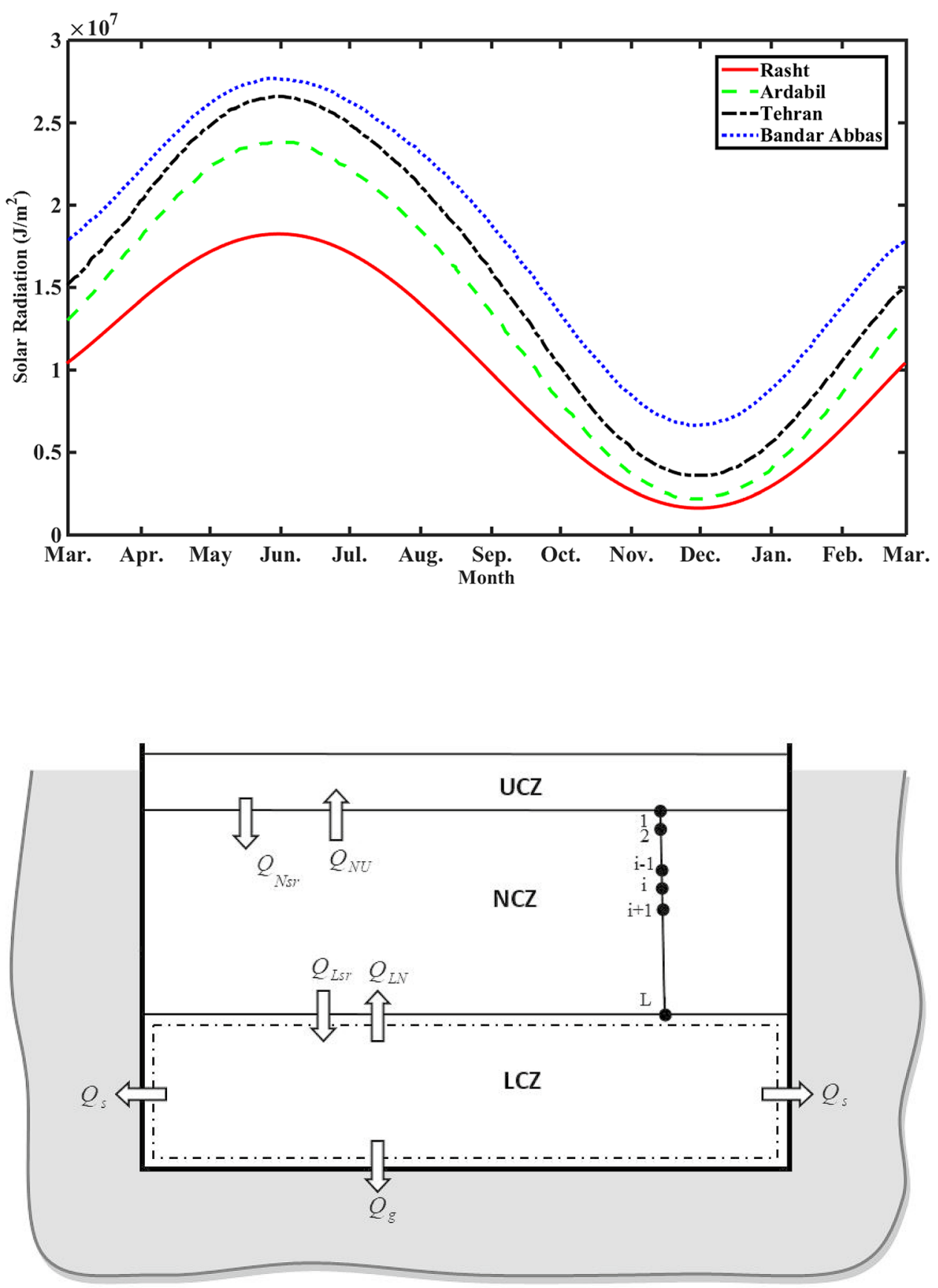

Fig. 3 The heat losses and gain in the solar pond
The performance of the SGSP depends on the amount of the solar irradiance on the surface of the pond and the heat losses from the three zones to the ground and atmosphere. The amount of the heat loss and gain could be different for these three layers. Many researchers such as Ali [4], Wang and Akbarzadeh [45] and Jaefarzadeh [21] have presented several models for estimating the solar pond's performance. In this study, the Jaefarzadeh's model [21] was applied to obtain the temperature of the storage layer.

\section{Mathematical modeling}

\subsection{Problem statement}

In this study, the SGSP with the surface area of $20 \times 20$ $\mathrm{m}^{2}$ and a depth of $1.1 \mathrm{~m}$ was considered. The thickness of upper, gradient and storage zones of the SGSP was selected 20,50 and $40 \mathrm{~cm}$, respectively. Because the area 
of the bottom of the solar pond was large enough, the heat losses from the sidewalls of the SGSP could not be considered. The shading effect is important to calculate the performance of the small solar pond [24, 26, 27]. In this study, since the surface of solar pond was assumed to be large enough, the shading effect was not considered. In order to decrease the heat losses from the side walls and the bottom of solar ponds, it is necessary to use insulations to reduce the heat transfer from the walls of solar ponds. There are different types of thermal insulation with various properties. Climate, lifetime, flammability, toxicity, thermal conductivity, ease of installation and cost are the effective parameters to choose a proper insulation material. In this study, polyurethane was used for insulation material. Because polyurethane has a low cost and thermal conductivity, and it can be easily installed, it is a suitable thermal insulation. The cost of polyurethane material is about $16,000 \mathrm{IR} / \mathrm{cm}$ for each square meter, and the installation cost is $4500 \mathrm{IR} /$ $\mathrm{m}^{2}$. Table 3 shows the properties of SGSP elements.

The properties of the solar pond were selected as done in reference [21] and are indicated in Table 3.

Some simplifying assumptions were applied to simulate the solar pond:

1 The temperatures and densities of salt water of the upper and lower layers were uniforms.

2 The depths of solar pond layers were constant.

3 One-dimensional unsteady-state heat transfer occurred inside the solar pond.

4 Environmental effects such as evaporation, rain and daily wind were neglected.

5 The upper layer temperature was equal to the ambient temperature.

6 At a certain distance in the lateral direction $\left(Q_{s} \approx 0\right)$, the ground temperature was equal to the mean annual ambient temperature.

7 The depth of the water table was $20 \mathrm{~m}$ and had a constant temperature of $17^{\circ} \mathrm{C}$.

\subsection{Governing equations}

The main mechanism of heat transfer in the NCZ is conduction from LCZ to UZC. By writing the energy balance over a Cartesian element in the NCZ, the partial differential equation could be obtained:

$\rho c_{P} \frac{\partial T}{\partial t}=\frac{\partial}{\partial z}\left(k \frac{\partial T}{\partial z}\right)+E(z, t)$.

Equation (1) is the one-dimensional unsteady-state heat conduction equation with heat generation term. According to Eq. (1), temperature and heat source term, which
Table 2 Average monthly ambient temperatures for selected cities $\left({ }^{\circ} \mathrm{C}\right)$

\begin{tabular}{lllll}
\hline Month & Bandar Abbas & Tehran & Ardabil & Rasht \\
\hline January & 17.8 & 3.7 & -2.5 & 6.8 \\
February & 19.3 & 5.8 & -0.9 & 6.9 \\
March & 22.5 & 10.4 & 3.5 & 9.2 \\
April & 26.4 & 16.7 & 9.8 & 14.3 \\
May & 30.7 & 22 & 12.9 & 19.2 \\
June & 33.3 & 27.4 & 16.1 & 23.5 \\
July & 34.3 & 30.2 & 18.3 & 25.2 \\
August & 33.9 & 29.5 & 18.2 & 25.1 \\
September & 32.3 & 25.5 & 15.7 & 22.1 \\
October & 29.3 & 18.9 & 11.1 & 17.5 \\
November & 24.2 & 11.5 & 5.8 & 12.8 \\
December & 19.7 & 5.9 & 0.6 & 8.9 \\
Average & 27 & 17.3 & 9 & 16 \\
\hline
\end{tabular}

Table 3 Properties of solar pond elements

\begin{tabular}{lll}
\hline Parameter & Property & Value \\
\hline Area & ---- & $400 \mathrm{~m}^{2}$ \\
UCZ thickness & ---- & $20 \mathrm{~cm}$ \\
NCZ thickness & ---- & $50 \mathrm{~cm}$ \\
LCZ thickness & ---- & $40 \mathrm{~cm}$ \\
Polyurethane & $k_{\text {ins }}$ & $0.03 \mathrm{~W} / \mathrm{m}^{\circ} \mathrm{C}$ \\
& $\rho_{\text {ins }}$ & $36 \mathrm{~kg} / \mathrm{m}^{3}$ \\
Cement & $k_{c}$ & $0.5 \mathrm{~W} / \mathrm{m}^{\circ} \mathrm{C}$ \\
& $\rho_{c}$ & $1330 \mathrm{~kg} / \mathrm{m}^{3}$ \\
& Width & $20 \mathrm{~cm}$ \\
Ground & $k_{g}$ & $3.50 \mathrm{~W} / \mathrm{m}^{\circ} \mathrm{C}$ \\
\hline
\end{tabular}

represents the solar radiation absorption within the middle layer, change with time and depth of the SGSP.

The absorption rate of solar irradiance was estimated by:

$E(z, t)=\frac{-\mathrm{d}}{\mathrm{d} z}\left(\frac{A_{e}+A_{\mathrm{sh}} \xi}{A} I_{R}(z, t)\right)$.

The attenuation of the solar irradiance in the solar pond can be determined as follows [39] [46]:

$I_{R}(z, t)=I_{R}(0, t)(0.36-0.08 \ln z)$.

The thermo-physical properties of the salt water were obtained from [24]:

$k=0.5553-0.0000813 c+0.0008(T-20)$

$\rho=998+0.65 c-0.4(T-20)$

\section{SN Applied Sciences}


$c_{P}=4180-4.39 c+0.0048 c^{2}$.

By using Crank-Nicolson method, Eq. (1) can be discrete as:

$\rho_{i} c_{p_{i}} \frac{T_{i}^{n+1}-T_{i}^{n}}{\Delta t}=\frac{1}{\Delta z}\left(\left.k_{i+\frac{1}{2}} \frac{\partial T}{\partial z}\right|_{i+\frac{1}{2}}-\left.k_{i-\frac{1}{2}} \frac{\partial T}{\partial z}\right|_{i-\frac{1}{2}}\right)+E^{n+\frac{1}{2}}(z, t)$
$T_{L}^{n+1}=\frac{\Delta t}{\rho c_{P} D_{L}}\left[I_{R}^{n}+k \frac{T_{L-1}^{n}-T_{L}^{n}}{\Delta z}+\frac{k_{s} A_{s}}{A} \frac{T_{s}^{n}-T_{L}^{n}}{\Delta y}+k_{g} \frac{T_{g}^{n}-T_{L}^{n}}{\Delta g}\right]+T_{L}^{n}$

In the horizontal direction, the ground temperature is equal to the average annual ambient temperature of the selected zones [6]. The groundwater table temperature is also considered equal to $17^{\circ} \mathrm{C}$ at a depth of $20 \mathrm{~m}$ [5].

Finally, it was developed as follows:

$\rho_{i} c_{p_{i}} \frac{T_{i}^{n+1}-T_{i}^{n}}{\Delta t}=\frac{1}{2 \Delta z^{2}}\left[k_{i+1 / 2}\left(T_{i+1}^{n+1}-T_{i}^{n+1}\right)+k_{i-1 / 2}\left(T_{i-1}^{n+1}-T_{i}^{n+1}\right)\right]+\frac{1}{2 \Delta z^{2}}\left[k_{i+1 / 2}\left(T_{i+1}^{n}-T_{i}^{n}\right)+k_{i-1 / 2}\left(T_{i-1}^{n}-T_{i}^{n}\right)\right]+E_{i}^{n+1 / 2}$.

Equation (8) is a second-order partial differential equation, dependent on time. Therefore, to construct a solution, Eq. (8) requires two boundary conditions and one initial condition. Initially, the solar pond was at uniform temperature which was equal to the ambient temperature. Two boundary conditions were also derived by applying energy balance over the UCZ and LCZ:

For UCZ:

$T_{U}=T_{\mathrm{amb}}$.

For LCZ:

$\rho A D_{L} c_{p} \frac{\partial T}{\partial t}=Q_{L s r}-Q_{L N}-Q_{s}-Q_{g}$

where

$Q_{L s r}=A_{e} I_{R}+\xi A_{s h} I_{R}$

$Q_{L N}=-\left.k A \frac{\partial T}{\partial z}\right|_{Z=D_{U}+D_{N}}$

$Q_{s}=-\left.k_{s} A_{s} \frac{\partial T}{\partial y}\right|_{\text {side }}$

$Q_{g}=-\left.k A \frac{\partial T}{\partial z}\right|_{z=D_{N}+D_{U}+D_{L}}$.

Equations (9) and (10) could be discrete as:

For UCZ:

$T_{1}^{n}=T_{\text {amb }}^{n}$.

For LCZ:

$\rho c_{P} A D_{L} \frac{T_{L}^{n+1}-T_{L}^{n}}{\Delta t}=Q_{L s r}-Q_{L N}-Q_{s}-Q_{g}$.

Therefore:

\subsection{Economic analysis}

The heat transfer from the bottom of the SGSP can be found as below [33]:

$Q_{w}=-U A_{g}\left(T_{L}-T_{g}\right)=U A_{g} \Delta T$

where $A_{g}$ is the surface area of the bottom wall, $T_{g}$ is the external wall temperature, $T_{L}$, changes with time and calculates by Eq. (17), is the LCZ temperature of the solar pond and $U$ is the overall heat transfer coefficient and explicitly given below:

$U=\frac{1}{R_{\text {tot }}}$

where $\mathrm{R}_{\text {wall }} R_{\text {tot }}$ is the total thermal resistance of wall materials and can be written as:

$R_{\text {tot }}=\frac{1}{h_{i}}+\frac{x_{1}}{k_{1}}+\frac{x_{2}}{k_{2}}+\cdots+\frac{x_{n}}{k_{n}}$

where $h_{i} h_{i}$ is the convection heat transfer coefficient based on the inside surface area of the bottom of the SGSP, $x$ and $k$ are the thickness and thermal conductivity of the wall layers, respectively. $\Delta U$ is the difference between the total heat transfer coefficients of the bottom of the SGSP without and with the insulated wall, which can be expressed as:

$\Delta U=U_{\text {unins }}-U_{\text {ins }}=\frac{1}{R_{\text {tot }}}-\frac{1}{R_{\text {tot }}+\left[\frac{x}{k}\right]_{\text {ins }}}$.

The annual energy requirement $\left(E_{a}\right)$ is a function of heat transfer from the surface of the SGSP $(Q)$, the total operating time of the SGSP $(\Delta t)$ and the coefficient of performance of the heater instead of the solar irradiance $\left(\eta_{s}\right)$ :

$E_{a}=\frac{Q \Delta t}{\eta_{s}}$.

Hence, annual energy required for heating per unit surface can be written by the following equation:

SN Applied Sciences 
$\frac{E_{a}}{A_{g}}=\frac{\Delta t \times \Delta T}{\left(R_{\mathrm{tot}}+\left[\frac{x}{k}\right]_{\mathrm{ins}}\right) \times \eta_{s}}$.

The heat transfer from the bottom of the SGSP depends on the insulation thickness. It is clear that the insulation thickness is inversely proportional to heat transfer.

A cost-benefit analysis should be applied in order to estimate the optimum insulation thickness. If the total cost, including the insulation and the energy consumption, is minimized, the optimum insulation thickness will be found.

In order to calculate the economic insulation, it is necessary to identify the ratio of life-cycle energy cost to the first year energy cost $\left(P_{1}\right)$ and the ratio of life-cycle expenditures incurred, because of the additional capital investment, to the initial investment $\left(P_{2}\right) . P_{1}$ is a function of market discount rate $(d)$, natural gas cost inflation rate (i) and life-cycle period $(N)$ as expressed by the following equation [12]:

$P_{1}=\frac{1}{d-i}\left[1-\left(\frac{1+i}{1+d}\right)^{N}\right]$.

If the rate of rising energy prices is equal to the rate of energy price discount for the whole year (or $d=i$ ), $P_{1}$ is given by:

$P_{1}=\frac{N}{1+i}$

$P_{2}$, is expressed as:

$P_{2}=1+P_{1} M_{s}-R_{V}(1+d)^{-N}$

where $M_{s}$ is the ratio of the annual maintenance and operation costs to the original first costs and $R_{v}$ is the ratio of the resale value to the first costs. If the maintenance and operation costs are zero, then $P_{2}=1$ [12].

The cost of insulation $\left(C_{i}\right)$ is written as:

$C_{i}=x_{i} C_{A}$

where $C_{A}$ and $x_{i}$ are the costs of thermal insulation per unit volume $\left(I R / \mathrm{m}^{3}\right)$ and the thermal insulation thickness, respectively. Equation (27) shows that there is a linear relation between the cost of insulation and insulation thickness. The net energy cost savings for heating over the lifetime from the use of insulation can be written by following equation:

$S=\left(\frac{P_{1} C_{E} \Delta U \Delta T \Delta t}{\eta_{s}}\right)-P_{2} C_{A} x_{i}$

If the total cost of energy and insulation is minimized, the optimum insulation thickness will be obtained. Hence, the optimum thickness $x_{\text {opt }} x_{\text {opt }}$ is calculated using the following equation:

$x_{\mathrm{opt}}=\frac{\left[\sqrt{\frac{R_{\text {wall }}^{2} k_{\text {ins }}}{P_{2} \times C_{A} \times 10^{3}}\left(\frac{P_{1} C_{E} \Delta T \Delta t}{\eta_{\mathrm{s}}}\right)}-R_{\text {wall }}^{2} k_{\text {ins }}\right]}{R_{\text {wall }}}$.

Table 4 shows the necessary input data for calculating the optimum insulation thickness, cost and energy savings for the SGSP. Since the LCZ temperature increases and decreases during the usage, for estimating the optimum insulation thickness, LCZ's hourly temperature for every thickness of insulation must be calculated by Eq. (17).

\section{Results and discussion}

The optimum insulation thickness, cost saving and energy saving were obtained for the SGSP under different climate conditions. If the thickness of thermal insulation is increased, the heat conduction from the bottom of solar pond will be decreased; on the other hand, the cost of insulation will be increased. Therefore, there exists a minimum total cost of insulation and energy in which optimum thickness of insulation is obtained.

The temperature variation of the LCZ from the computer simulation for the duration of one year is shown in Fig. 4. This figure compares the results of the present research and Jaefarzadeh's experimental data [21] for $50 \mathrm{~mm}$ thickness of insulation in the city of Mashhad, which is located in the northeast of Iran. The simulated LCZ temperatures as obtained in this work showed good agreement with the LCZ temperatures reported in [21]. There is an average deviation of around $5 \%$ between simulated and experimental temperatures.

The dissimilarity between the mathematical model and the experimental temperatures could be due to the simplicity assumptions used to simulate the SGSP, such as elimination of environmental effects, which could

Table 4 Necessary input data

\begin{tabular}{lll}
\hline Parameter & Unit & Values \\
\hline Life-cycle period $(\mathrm{N})$ & Years & 15 \\
Fuel & - & Natural gas \\
Gas tariffs & $\mathrm{IR} / \mathrm{m}^{3}$ & 1000 \\
$\mathrm{~d}$ & $\%$ & 20.6 \\
$\mathrm{i}$ & $\%$ & 15 \\
$\mathrm{P}_{1}$ & - & 10.79 \\
$\eta_{s}$ & - & 0.93 \\
\hline
\end{tabular}


occurred in the real conditions; LCZ and UCZ were supposed as a single cell with a uniform temperature.

The optimum insulation thickness of the bottom of the SGSP located in the mention cities is shown in Fig. 5. This Figure presents variations in the cost of energy consumption, the insulation cost and the total cost with respect to the insulation thickness. As can be seen, the optimum insulation thickness was obtained when the total cost was minimized. Also, there was a nonlinear relation between the cost saving energy and the insulation thickness. However, there was a linear relation between the cost of the thermal insulation and the insulation thickness.

As shown in Fig. 5, the optimum insulation thicknesses were $122,92,62$ and $66 \mathrm{~mm}$ when the SGSP was located in Bandar Abbas (zone 1), Tehran (zone 2), Ardabil (zone 3 ) and Rasht (zone 4), respectively. It was notable that the value of optimum insulation thickness depended on the amount of solar irradiance and the ambient temperature. The maximum and minimum, optimum insulation thickness were obtained in zones 1 and 3, respectively. Although the solar irradiance in the zone 3 was higher than that in the zone 4, the average annual ambient temperature in the latter was larger than that in the former. Therefore, the maximum temperature of the $L C Z$ and the optimum insulation thickness of the SGSP located in Rasht (zone 4) were larger than that located in Ardabil (zone 3).

Figure 6 shows the effect of the insulation thickness on cost savings over the lifetime for different zones. The cost saving was found to be the maximum value at an optimum insulation thickness. It could be observed that the value of cost saving was $48,854.3$ to $183,946 \mathrm{IR} / \mathrm{m}^{2}$ under different climate conditions. It was clear that the highest and lowest cost saving occurred in the zones 1 and 3, respectively.

Among all zones, zone 1 has the greatest solar radiation and the highest average annual ambient temperature, whereby the temperature of the LCZ in this zone reaches the highest value. However, zone 1 has the thickest insulation layer (that means the highest cost of insulation) compared to other zones. Since the temperature difference is a more effective parameter in thermal insulation, with respect to Eq. (27), the highest cost saving obtained in zone 1.
Table 5 presents the values of energy and cost savings at the optimum insulation thickness for different climate conditions. The maximum temperature of the LCZ for different cities in terms of the optimum insulation thickness is also shown in Table 5. As shown, the optimum insulation thickness was between 62 and $122 \mathrm{~mm}$, the cost savings varied from 48,854 to $183,946 \mathrm{IR} / \mathrm{m}^{2}$, and energy savings ranged $36.7 \%$ to $55.2 \%$ for different climate conditions. To summarize, the maximum insulation thickness, cost and energy saving were obtained for the zone 1.

The thermal behavior of the solar ponds with optimum insulation thickness over two years is shown in Fig. 7 for comparison purposes. It could be observed that the highest LCZ temperatures were obtained for the solar pond located in zone 1 in all months of the year; its maximum temperature was around $78.6^{\circ} \mathrm{C}$ (July) and the minimum temperature was around $41.3^{\circ} \mathrm{C}$ (January). As can be seen, the LCZ temperatures of the solar pond located in zone 1 are higher than the average monthly ambient temperatures of this zone (see Table 2), even in winter months. This result shows that the solar pond with optimum insulation thickness is suitable to provide desired heat for human beings uses even in winter months.

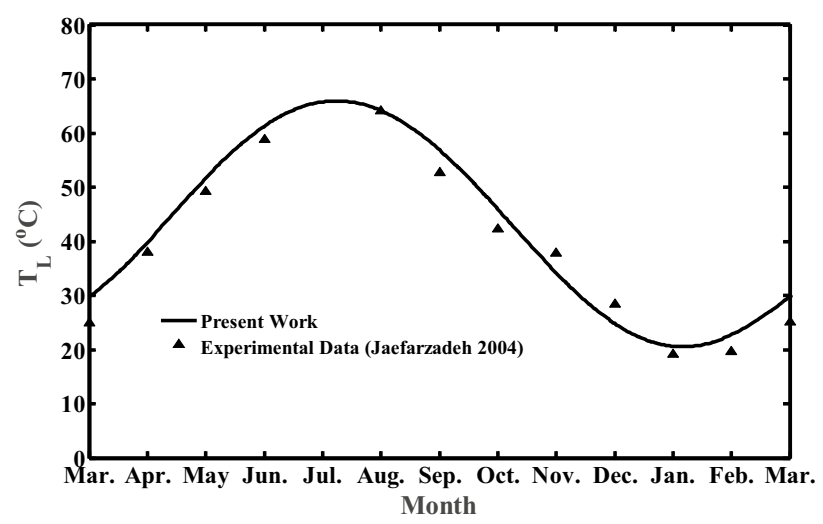

Fig. 4 Theoretical and experimental variation of the LCZ temperature for Mashhad
Table 5 Optimum insulation thickness, cost and energy savings under different climate conditions

\begin{tabular}{lllll}
\hline City (zone number) & $\begin{array}{l}\text { Maximum LCZ tem- } \\
\text { perature }\left({ }^{\circ} \mathrm{C}\right)\end{array}$ & $\begin{array}{l}\text { Optimum thick- } \\
\text { ness }(\mathrm{mm})\end{array}$ & Cost saving $\left(\mathrm{IR} / \mathrm{m}^{2}\right)$ & $\begin{array}{l}\text { Energy } \\
\text { saving } \\
(\%)\end{array}$ \\
\hline Bandar Abbas (1) & 80.8 & 122 & 183,946 & 55.2 \\
Tehran (2) & 73.4 & 92 & 106,606 & 47 \\
Ardabil (3) & 59.3 & 62 & 48,854 & 36.7 \\
Rasht (4) & 61.2 & 66 & 55,173 & 38.3 \\
\hline
\end{tabular}



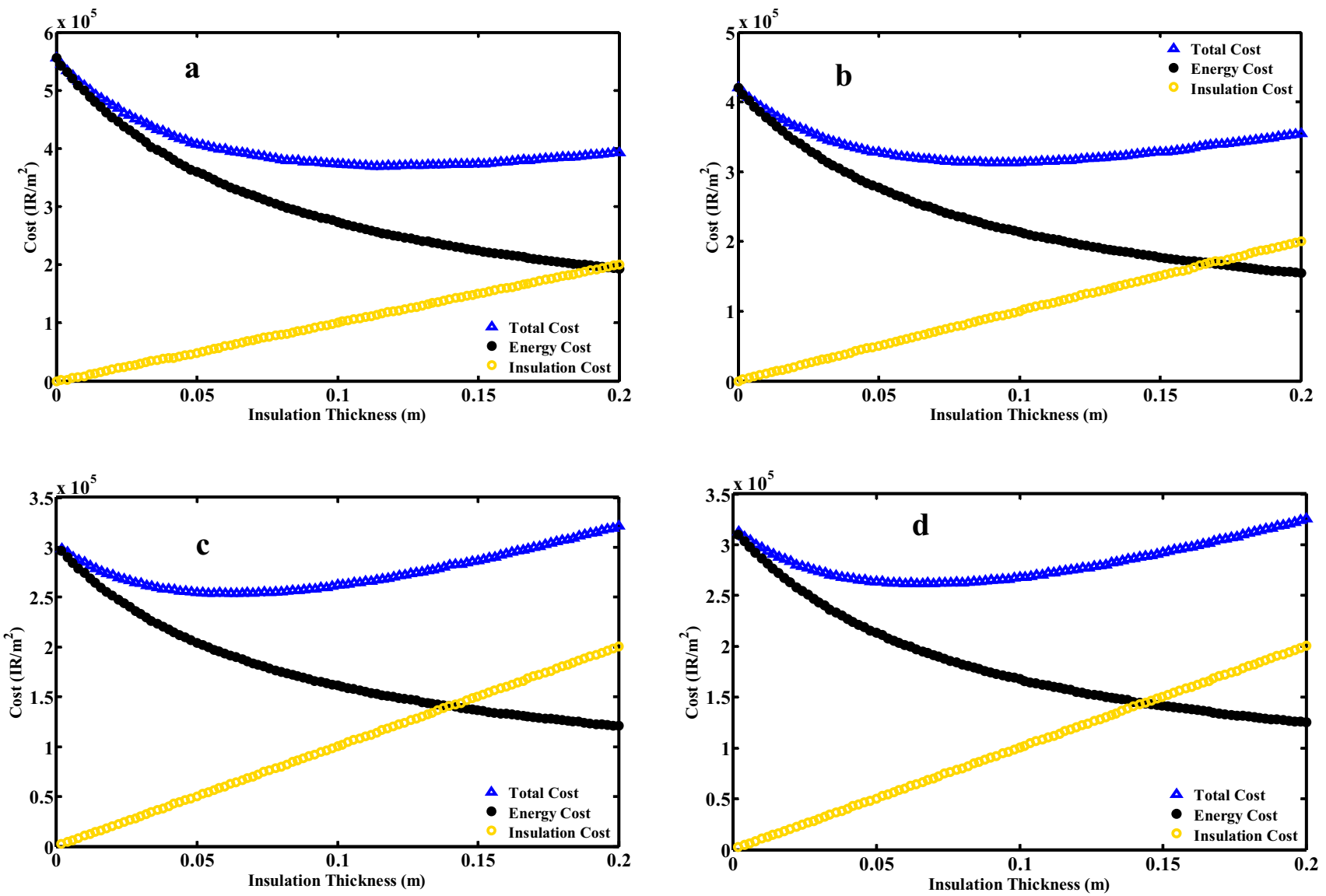

Fig. 5 Effect of insulation thickness on cost for a zone 1 (Bandar Abbas), b zone 2 (Tehran), c zone 3 (Ardabil), d zone 4 (Rasht)
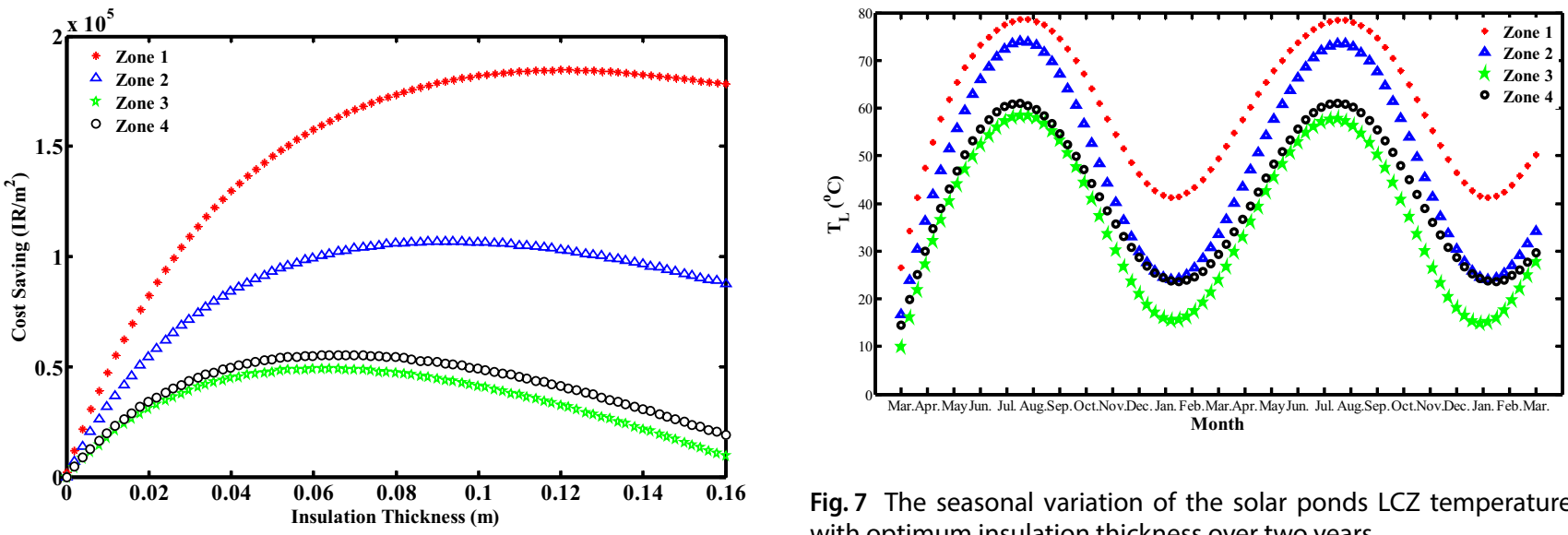

Fig. 7 The seasonal variation of the solar ponds LCZ temperature with optimum insulation thickness over two years

Fig. 6 Comparison cost saving for selected cities

\section{Conclusion}

In this study, the optimum insulation thickness in the SGSP's bottom wall was calculated in different climate conditions. For cost benefit analyses, four cities of Iran,

which were located in different solar radiation zones, were selected. The SGSP consisted of three distinct layers including UCZ, NCZ and LCZ. LCZ and UCZ were assumed to be perfectly mixed with a uniform temperature. The temperature of the UCZ was equal to the ambient temperature, and the LCZ temperature was also predicted using the one-dimensional transient heat 
transfer model. Heat transfer inside the SGSP was developed based on energy balance by the time-dependent one-dimensional mathematical heat transfer model. The optimum insulation thickness, cost and energy savings were determined over a solar pond lifetime of 15 years. The results showed that the climate conditions had a significant effect on the optimum insulation thickness and energy saving. Four cities, namely Bandar Abbas, Tehran, Ardabil and Rasht, were selected in four different climate conditions, and the optimum insulation thicknesses were obtained to be $112,92,62,66 \mathrm{~mm}$ for these climate conditions, respectively. The insulation on the bottom of the pond was the most economical in Bandar Abbas, in the zone 1. The cost saving range of the different regions was $48,854-183,946 \mathrm{I} / \mathrm{I} / \mathrm{m}^{2}$ and the energy saving ranged from 36.7 to $55.2 \%$ when the optimum insulation thickness was used. The solar pond located in zone 1 was supplied the desired heat for human uses even in winter months.

Acknowledgement This research did not receive any specific grant from funding agencies in the public, commercial or not-for-profit sectors.

\section{Compliance with ethical standards}

Conflict of interest The authors declare that they have no conflict of interest.

\section{References}

1. Abdullah AA, Lindsay KA, AbdelGawad AF (2016) Construction of sustainable heat extraction system and a new scheme of temperature measurement in an experimental solar pond for performance enhancement. Sol Energy 130:10-24. https://doi. org/10.1016/j.solener.2016.02.005

2. Al-Nimr MdA (2014) Al-Dafaie AMA Using nanofluids in enhancing the performance of a novel two-layer solar pond. Energy 68:318-326. https://doi.org/10.1016/j.energy.2014.03.023

3. Alcaraz A, Valderrama C, Cortina JL, Akbarzadeh A, Farran A (2016) Enhancing the efficiency of solar pond heat extraction by using both lateral and bottom heat exchangers. Sol Energy 134:82-94. https://doi.org/10.1016/j.solener.2016.04.025

4. Ali $\mathrm{H}$ (1986) Mathematical modelling of salt gradient solar pond performance. Int J Energy Res 10:377-384

5. Amigo J, Meza F, Suárez F (2017) A transient model for temperature prediction in a salt-gradient solar pond and the ground beneath it. Energy 132:257-268. https://doi.org/10.1016/j.energ y.2017.05.063

6. Amigo J, Suárez F (2018) Ground heat storage beneath saltgradient solar ponds under constant heat demand. Energy 144:657-668. https://doi.org/10.1016/j.energy.2017.12.066

7. Atiz A, Bozkurt I, Karakilcik M (2019) Performance investigation of salt gradient cylindrical solar pond integrated and nonintegrated with evacuated tube solar collectors. Int J Energy Res
8. Beiki H, Dadvar M, Halladj R (2009) Pore network model for catalytic dehydration of methanol at particle level. AIChE J 55:442-449

9. Beiki H, Keramati M (2019) Improvement of methane production from sugar beet wastes using $\mathrm{TiO} 2$ and $\mathrm{Fe} 3 \mathrm{O} 4$ nanoparticles and chitosan micropowder additives. Appl Biochem Biotechnol 189:13-25. https://doi.org/10.1007/s12010-01902987-2

10. Beiki H, Soukhtanlou E (2019) Improvement of salt gradient solar ponds' performance using nanoparticles inside the storage layer. Appl Nanosci 9:243-254. https://doi.org/10.1007/s1320 4-018-0906-6

11. Beniwal R, Singh RV, Chaudhary D (1985) Heat losses from a salt-gradient solar pond. Appl Energy 19:273-285

12. Bolattürk A (2008) Optimum insulation thicknesses for building walls with respect to cooling and heating degree-hours in the warmest zone of Turkey. Build Environ 43:1055-1064

13. Bozkurt I, Deniz S, Karakilcik M, Dincer I (2015) Performance assessment of a magnesium chloride saturated solar pond. Renewab Energy 78:35-41. https://doi.org/10.1016/j.renen e.2014.12.060

14. Ding L, Akbarzadeh A, Tan L (2018) A review of power generation with thermoelectric system and its alternative with solar ponds. Renew Sustain Energy Rev 81:799-812

15. Duffie JA, Beckman WA (1980) Solar engineering of thermal processes

16. El-Sebaii A, Ramadan M, Aboul-Enein S, Khallaf A (2011) History of the solar ponds: a review study. Renew Sustain Energy Rev 15:3319-3325

17. Elsarrag E, Igobo ON, Alhorr Y, Davies PA (2016) Solar pond powered liquid desiccant evaporative cooling. Renew Sustain Energy Rev 58:124-140. https://doi.org/10.1016/j.rser.2015.12.053

18. Global horizontal irradiation-Iran (2019). www.solargis.info/doc/ free-solar-radiation-maps-GHI

19. Idehai IM, Akujieze CN (2015) Estimation of landfill gas and its renewable energy potential in Lagos Nigeria. Int J Energy Environ Eng 6:329-343

20. Iran Oil Ministry Annual Bulletin (2016), 5th edn. Iran Oil Ministry

21. Jaefarzadeh MR (2004) Thermal behavior of a small salinitygradient solar pond with wall shading effect. Sol Energy 77:281-290

22. Joshi P, Tiwari GN (2018) Effect of cooling condensing cover on the performance of $\mathrm{N}$-identical photovoltaic thermalcompound parabolic concentrator active solar still: a comparative study. Int J Energy Environ Eng 9:473-498. https://doi. org/10.1007/s40095-018-0276-6

23. Jubran B, El-Baz A, Hamdan M, Badran A (1996) Experimental investigation of local clays and clay schemes as liners for solar ponds. Int J Energy Res 20:637-642

24. Karakilcik M, Dincer I, Bozkurt I, Atiz A (2013) Performance assessment of a solar pond with and without shading effect. Energy Convers Manage 65:98-107

25. Keramati $\mathrm{M}$, Beiki $\mathrm{H}$ (2017) The effect of $\mathrm{pH}$ adjustment together with different substrate to inoculum ratios on biogas production from sugar beet wastes in an anaerobic digester. J Energy Manag Technol 1:6-11

26. Khalilian $M$ (2017) Energetic performance analysis of solar pond with and without shading effect. Sol Energy 157:860-868

27. Khalilian M (2018) Experimental and numerical investigations of the thermal behavior of small solar ponds with wall shading effect. Sol Energy 159:55-65

28. Khan MS, Abid M, Ratlamwala TAH (2018) Energy, exergy and economic feasibility analyses of a $60 \mathrm{MW}$ conventional steam power plant integrated with parabolic trough solar collectors using nanofluids iranian journal of science and technology. Trans Mech Eng. https://doi.org/10.1007/s40997-018-0149-x 
29. Khodabandeh E, Safaei MR, Akbari S, Akbari OA, Alrashed AAAA (2018) Application of nanofluid to improve the thermal performance of horizontal spiral coil utilized in solar ponds: geometric study. Renewab Energy 122:1-16. https://doi.org/10.1016/j. renene.2018.01.023

30. Kreider JF, Kreith F (1981) Solar energy handbook. Springer, Berlin

31. Kurt H, Ozkaymak M, Binark AK (2006) Experimental and numerical analysis of sodium-carbonate salt gradient solar-pond performance under simulated solar-radiation. Appl Energy 83:324-342

32. Liu H, Jiang L, Wu D, Sun W (2015) Experiment and simulation study of a trapezoidal salt gradient solar pond. Sol Energy 122:1225-1234. https://doi.org/10.1016/j.solener.2015.09.006

33. Mahlia T, Iqbal A (2010) Cost benefits analysis and emission reductions of optimum thickness and air gaps for selected insulation materials for building walls in Maldives. Energy 35:2242-2250

34. Mansouri Kouhestani F, Byrne J, Johnson D, Spencer L, Hazendonk P, Brown B (2019) Evaluating solar energy technical and economic potential on rooftops in an urban setting: the city of Lethbridge Canada. Int J Energy Environ Eng 10:13-32. https:// doi.org/10.1007/s40095-018-0289-1

35. Ranjan KR, Kaushik SC (2014) Thermodynamic and economic feasibility of solar ponds for various thermal applications: a comprehensive review. Renew Sustain Energy Rev 32:123-139. https ://doi.org/10.1016/j.rser.2014.01.020

36. Rostamzadeh $H$, Nourani $P$ (2019) Investigating potential benefits of a salinity gradient solar pond for ejector refrigeration cycle coupled with a thermoelectric generator. Energy 172:675690. https://doi.org/10.1016/j.energy.2019.01.167

37. Sakhrieh A, Al-Salaymeh A (2013) Experimental and numerical investigations of salt gradient solar pond under Jordanian climate conditions. Energy Convers Manage 65:725-728

38. Salata F, Coppi M (2014) A first approach study on the desalination of sea water using heat transformers powered by solar ponds. Appl Energy 136:611-618. https://doi.org/10.1016/j. apenergy.2014.09.079

39. Sayer AH, Al-Hussaini $H$, Campbell AN (2016) New theoretical modelling of heat transfer in solar ponds. Sol Energy 125:207218. https://doi.org/10.1016/j.solener.2015.12.015

40. Sayer AH, Monjezi AA (2018) Campbell ANJATE Behaviour of a salinity gradient solar pond during two years and the impact of zonal thickness variation on its performance. Appl Therm Eng 130:1191-1198

41. Sezai I, Taşdemiroğlu E (1995) Effect of bottom reflectivity on ground heat losses for solar ponds. Sol Energy 55:311-319

42. Shahmohammadi $P$, Beiki $H$ (2016) A numerical investigation of $\mathrm{Y}$-Al2O3-water nanofluids heat transfer and pressure drop in a shell and tube heat exchanger. Transp Phenomena Nano Micro Scales 4:29-35

43. Shamshirgaran S, Khalaji Assadi M, Al-Kayiem HH, Viswanatha Sharma K (2018) Energetic and exergetic performance of a solar flat-plate collector working with Cu nanofluid. J Sol Energy Eng 140:031002-031002-031008. https://doi.org/10.1115/1.40390 18

44. Wang J, Seyed-Yagoobi J (1995) Effect of water turbidity on thermal performance of a salt-gradient solar pond. Sol Energy 54:301-308

45. Wang Y, Akbarzadeh A (1983) A parametric study on solar ponds. Sol Energy 30:555-562

46. Zhang ZM, Wang YF (1990) A study on the thermal storage of the ground beneath solar ponds by computer simulation. Sol Energy 44:243-248. https://doi.org/10.1016/0038092X(90)90052-E

Publisher's Note Springer Nature remains neutral with regard to jurisdictional claims in published maps and institutional affiliations. 